УДК 622.361 .2

DOI: https://doi.org/10.26642/ten-2021-2(88)-129-134

\author{
В.В. Котенко, к.т.н., доц. \\ С.І. Башинський, к.т.н., доц. \\ I.А. Піскун, аспірант \\ Державний університет «Житомирська політехніка»
}

\title{
Застосування методу Пірсона для отримання залежностей розподілу хімічних елементів у межах родовища каоліну
}

\begin{abstract}
Розглянуто доиільність застосування методу кореляиії Пірсона для знаходження взаємозв'язків між відсотковими співвідношеннями вмісту складових хімічних елементів первинного каоліну. Розглянуто суть та базові принципи розрахунку коефіцієнта кореляції за допомогою методу Пірсона, надано коротку характеристику вихідних даних, на основі яких може бути виконано даний розрахунок. Описано приклад інтервальної градації ступеня інтенсивності коефіцієнта кореляиії, яку рекомендується застосовувати під час роботи з емпіричними даними. Виконано побудову матриці кореляційних залежностей між складовими хімічними елементами первинного каоліну на основі результатів хімічного аналізу, отриманих у прочесі проведення геологорозвідувальних робіт за умов Йосипівського родовища первинного каоліну. Визначено ступінь інтенсивності кореляційних зв'язків низки складових хімічних елементів первинного каоліну. Виведено лінійні рівняння для опису залежностей між складовими елементами 3 коефіиієнтом кореляції середнього та низького, але наближеного до середнього, ступеня інтенсивності.
\end{abstract}

Ключові слова: коефічієнт кореляції; метод кореляції Пірсона; каолін первинний; хімічні складові елементи каоліну.

Постановка проблеми. За своєю природою та властивостями, каолін $є$ досить унікальною, цінною та незамінною сировиною для багатьох галузей промисловості. Пов'язано це насамперед 3 тим, що продукти видобутку та збагачення каолінової сировини необхідні для виробництва матеріалів широкого спектра призначення. Зокрема, каолін характеризується інертністю щодо кислих і лужних розчинів, високою вогнетривкістю, властивістю утворювати 3 водою пластичну масу. Ці властивості дають змогу його використання у виробництві тонкої, господарської та санітарної кераміки, електрокераміки, радіокераміки, вогнетривких виробів, силуміну, скла та низку інших елементів народного і технічного вжитку. Висока дисперсність, білий колір, діелектричні властивості та хімічна інертність дають змогу для використання каоліну як наповнювача під час виготовлення паперу, гумотехнічних, кабельних, пластмасових виробів, парфумів тощо.

Можливість використання каоліну, або продуктів його збагачення в тій чи іншій галузі промисловості, насамперед зумовлена його хімічним складом. Норми вмісту хімічних компонентів, що входять до складу каоліну, чітко регламентуються діючими стандартами якості для всіх галузей промисловості, де він використовується [1].

Характерною негативною особливістю каолінової сировини $є$ значна мінливість ії хімічного складу спричинена умовами генезису каолінових родовищ. Така особливість дуже часто призводить до зниження економічного ефекту від видобування та реалізації каолінової продукції, і збільшення кількості пов'язаних 3 цим непередбачуваних виробничих витрат. Надмірний вміст окремих хімічних сполук значною мірою може погіршувати фізико-механічні властивості каоліну, а в окремих випадках унеможливлює його використання в ряді галузей. Тому, встановлення кореляційних залежностей між основними хімічними елементами, які входять у склад каоліну дозволить підвищити точність виконання геометризації типових каолінових родовищ, що забезпечить можливість їх селективного відпрацювання з метою усереднення або приведення до необхідних значень якості кінцевої сировини.

Аналіз останніх досліджень та публікацій. Кореляційний аналіз як науковий метод досить часто використовується на початковому етапі вирішення проблем статистичного аналізу масиву даних у різних галузях наукових досліджень. У проблемі статистичного аналізу залежностей і побудови регресійних моделей він дає змогу встановити сам факт існування, або відсутності зв'язку між змінними та оцінити ступінь інтенсивності такого зв'язку. Приклади застосування цього показника з метою підтвердження або спростування взаємозв'язків між окремо взятими параметрами масиву даних часто можна побачити у роботах закордонних дослідників [2-4].

У роботах В.С. Білецького, присвячених моделюванню процесів збагачення корисних копалин, розглянуто особливості застосування математичної статистики, зокрема і методів кореляції 3 метою отримання статистичних математичних моделей під час дослідження мінеральної сировини на збагачуваність. Отримані результати були застосовані автором для визначення рівня зв'язку вхідних і 
вихідних параметрів мінеральної сировини, аналізів параметрів та побудови математичної моделі процесу збагачення мінеральної сировини [5].

Метою дослідження є обгрунтування доцільності застосування методу Пірсона для встановлення кореляційних зв'язків між складовими хімічними елементами каоліну на основі хімічного аналізу, отриманого в результаті виконання геологорозвідувальних робіт.

Викладення основного матеріалу. Встановлення кореляційних залежностей базується на використанні масиву даних у вигляді результатів хімічного аналізу, отриманих у процесі виконання геологорозвідувальних робіт за умов Йосипівського родовища первинного каоліну. Встановлення кореляційних зв’язків між двома дослідними елементами базується на визначенні коефіцієнта кореляції, який безпосередньо є індикатором ступеня інтенсивності цих зв'язків. Для встановлення кореляційних зв'язків між хімічними елементами у складі первинного каоліну Йосипівського родовища використано метод кореляції Пірсона [6].

Коефіцієнт кореляції Пірсона (ККП) показує силу кореляційних взаємозв’язків для двох змінних $X$ та $У$. Цей показник широко використовується у науці для вимірювання ступеня лінійної залежності між двома змінними [7]. 3 точки зору математики, ККП між двома змінними рівний коваріації цих двох змінних, або сумі добутків відхилень, поділеній на добуток їх стандартних відхилень [8]. ККП може бути виражений таким рівнянням:

$$
r_{x y}=\frac{\sum_{i=1}^{m}\left(x_{i}-\bar{x}\right)\left(y_{i}-\bar{y}\right)}{\sqrt{\sum_{i=1}^{m}\left(x_{i}-\bar{x}\right)^{2} \sum_{i=1}^{m}\left(y_{i}-\bar{y}\right)^{2}}},
$$

де $x_{i}$ та $y_{i}$ - змінні масиву даних;

$\bar{x}$ та $\bar{y}$ - вибіркові середні;

$r_{x y}$ - коефіцієнт кореляції Пірсона.

ККП може набувати значень від -1 до 1. Значення +1 означає, що залежність між дослідними зразками $\epsilon$ лінійною і всі точки функції лежать на прямій, яка відображає зростання $У$ під час зростання $X$. Значення -1 означає, що всі точки лежать на прямій, яка відображає зменшення $У$ за умови зростання $X$. Якщо ККП рівний нулю, то лінійна кореляція між дослідними значеннями не існує [9]. Оскільки значення ККП за використання емпіричними даними практично ніколи не дорівнює цілим числам, для надання оцінки сталості взаємозв'язків між порівнювальними показниками використовують інтервальні проміжки, наведені у таблиці 1.

Інтервальна градація ступеня інтенсивності коефіцієнта корелящії

Таблиия 1

\begin{tabular}{|c|c|c|}
\hline \multirow{2}{*}{ Ступінь інтенсивності кореляції } & \multicolumn{2}{|c|}{ Значення ККП } \\
\cline { 2 - 3 } & від'смне & додатнє \\
\hline відсутня & від 0,0 до $-0,1$ & від 0,0 до 0,1 \\
\hline низька & від $-0,1$ до $-0,3$ & від 0,1 до 0,3 \\
\hline середня & від $-0,3$ до $-0,5$ & від 0,3 до 0,5 \\
\hline висока & від $-0,5$ до -1 & від 0,5 до 1 \\
\hline
\end{tabular}

Масив даних, що піддавалися безпосередньому аналізу, формувався впродовж багатьох років, і ці дані оновлювалися на різних етапах розвідки родовища. Основна частина масиву даних (68 \%) сформована результатами геологічних досліджень, які проводилися в період 1991-1992 рр. У процесі виконання розвідувальних робіт на різних етапах геологічного освоєння родовища, лише по кондиційних каолінах сумарно було пройдено 719,9 м розвідувальних свердловин, у результаті чого було відібрано 386 рядових проб на хімічний аналіз.

В основу вибору критеріїв для виконання пошуку сталих залежностей між розподілом хімічних компонентів у складі каоліну було покладено промислово-економічний вектор розвитку регіону, в межах якого знаходиться Йосипівське родовище первинного каоліну. Це зумовлено тим, що така сировина $є$ базовою для функціонування заводів та підприємств з виготовлення порцеляно-фаянсової продукції та будівельної кераміки, велика кількість яких зосереджена в межах Дубрівської каолінової провінції (на вибір місця розташування цих підприємств вплинув фактор наявності потужної сировинної бази, що на багато років закріпило розвиток економіки району саме в цьому напрямку), в межах якої, власне, розташоване i Йосипівське родовище первинного каоліну. Отож найефективнішим та найбільш раціональним, з економічної точки зору, буде застосування незбагаченого каоліну (каоліну-сирцю) Йосипівського родовища для забезпечення потреб виробництва вогнетривких виробів, будівельної, грубої й тонкої господарської кераміки.

Для забезпечення наведених вище потреб керамічної промисловості допускається застосування трьох марок каоліну-сирцю, а саме: 
- КШФ - каолін-сирець, придатний для виготовлення тонкої кераміки (художньої та господарської порцеляни, електротехнічної порцеляни);

- КШС - каолін-сирець, придатний для виготовлення санітарно-технічної кераміки;

- КШБ - каолін-сирець, придатний для виробництва будівельної кераміки.

Відповідно до «Інструкції із застосування Класифікації запасів і ресурсів корисних копалин державного фонду надр до родовищ каолінів», технічні вимоги до каоліну-сирцю мають регламентуватися згідно з ТУ У В.2.7-14.2-05468498-006-2007 «Каолін первинний, не збагачений» (табл. 2).

Таблиияя 2

Технічні вимоги до марок первинного каоліну (каоліну-сирињю) який може бути застосований у керамічній промисловості

\begin{tabular}{|c|c|c|c|c|}
\hline \multirow{2}{*}{ Найменування показника } & \multirow{2}{*}{$\begin{array}{c}\text { Позначення } \\
\text { показника }\end{array}$} & \multicolumn{3}{|c|}{$\begin{array}{c}\text { Нормативні вимоги } \\
\text { до марок }\end{array}$} \\
\cline { 3 - 5 } & & КШФ & \multicolumn{1}{|c|}{ КШС } & КШБ \\
\hline Масова частка оксиду заліза (не більше), \% & $\mathrm{Fe}_{2} \mathrm{O}_{3}$ & 0,8 & 0,8 & 1,0 \\
\hline Масова частка двоокису титану (не більше), \% & $\mathrm{TiO}_{2}$ & 0,3 & 0,4 & 0,4 \\
\hline Масова частка оксиду алюмінію (не менше), \% & $\mathrm{Al}_{2} \mathrm{O}_{3}$ & 15 & 14 & 14 \\
\hline Масова частка оксиду калію (не менше), \% & $\mathrm{K}_{2} \mathrm{O}$ & 4,5 & 3,0 & 3,0 \\
\hline Масова частка оксиду кальцію (не більше), \% & $\mathrm{CaO}$ & 0,6 & 0,8 & 0,8 \\
\hline Співвідношення масових часток оксидів калію та & - & 5,0 & 4,0 & - \\
\hline натрію (не менше) & - & 30,0 & 30,0 & 30,0 \\
\hline Втрати при пропалюванні (не менше), \% & ВПП & &
\end{tabular}

Проаналізувавши ряд вимог, які стосуються якості каоліну для керамічної промисловості (таблиця 2), було зроблено висновок про доцільність пошуку сталих кореляційних зв'язків між значеннями відсоткового вмісту таких компонентів: $\mathrm{Al}_{2} \mathrm{O}_{3}, \mathrm{Fe}_{2} \mathrm{O}_{3}, \mathrm{TiO}_{2}, \mathrm{~K}_{2} \mathrm{O}$, та ВПП.

Встановлення кореляційних зв’язків для масиву даних хімічного аналізу отриманих за результатами геолого-розвідувальних робіт на Йосипівському родовищі первинного каоліну, виконувалося за допомогою додатку Microsoft Excel 2019. Результатами обробки масиву даних є матриця кореляції, яка наведена у вигляді таблиці 3.

Матриия кореляційних залежностей між складовими хімічними елементами

Таблиия 3 первинного каоліну Йосипівського родовища

\begin{tabular}{|c|c|c|c|c|c|}
\hline Компоненти & $\mathbf{A l}_{2} \mathbf{O}_{3}$ & $\mathbf{F e}_{2} \mathbf{O}_{3}$ & $\mathbf{T i O}_{\mathbf{2}}$ & $\mathbf{K}_{2} \mathbf{O}$ & $\mathbf{B \Pi \Pi}$ \\
\hline $\mathbf{A l}_{2} \mathbf{O}_{3}$ & 1 & - & - & - & - \\
\hline $\mathbf{F e}_{2} \mathbf{O}_{3}$ & $-0,05$ & 1 & - & - & - \\
\hline $\mathbf{T i O}_{2}$ & 0,41 & $-0,16$ & 1 & - & - \\
\hline $\mathbf{K}_{2} \mathbf{O}$ & 0,25 & 0,23 & 0,29 & 1 & - \\
\hline $\mathbf{B \Pi \Pi}$ & 0,11 & $-0,17$ & $-0,24$ & $-0,42$ & 1 \\
\hline
\end{tabular}

У результаті виконання аналізу значень, відображених у вигляді матриці кореляції (табл. 2), було зроблено висновок, що зв'язки високого ступеня інтенсивності між порівнюваними елементами відсутні, проте, виявлені зв'язки середньої та низької інтенсивності. Зокрема, зв'язки середньої інтенсивності спостерігаються між вмістом двоокису титану і оксиду алюмінію $(0,41)$ та втратами при пропалюванні і оксидом калію $(-0,42)$. Зв'язки, які мають низький, але близький до середнього ступінь інтенсивності, також були розглянуті більш детально, до таких зв'язків належить: оксид калію та оксид алюмінію $(0,25)$; оксид калію та оксид заліза (0,23); оксид калію та двоокис титану $(0,29)$; втрати при пропалюванні та двоокис титану $(-0,24)$. Практично відсутніми є кореляційні зв'язки між: втратами при пропалюванні та оксидом алюмінію $(0,11)$; двоокисом титану і оксидом заліза $(-0,16)$; втратами при пропалюванні та оксидом заліза $(-0,17)$. Для середніх та низьких, але наближених до середніх зв'язків було побудовано графіки залежності вмісту з метою їх приведення у вигляд лінійних рівнянь (рис. 1). 


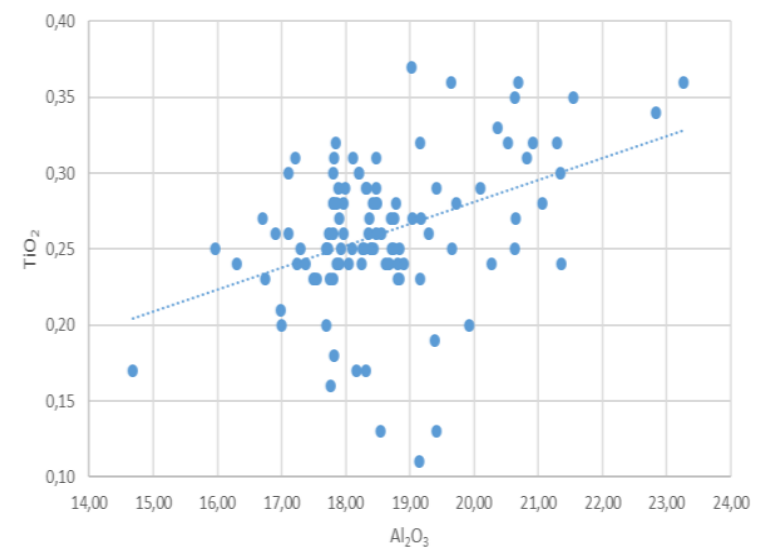

$a$

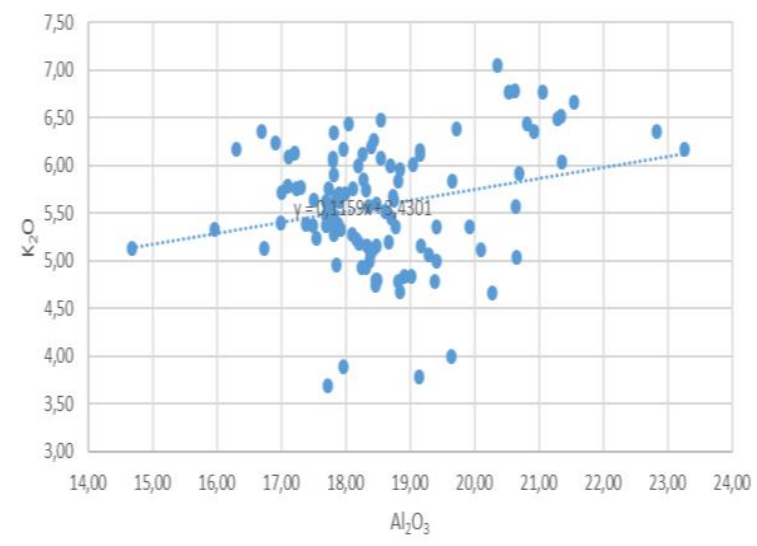

B

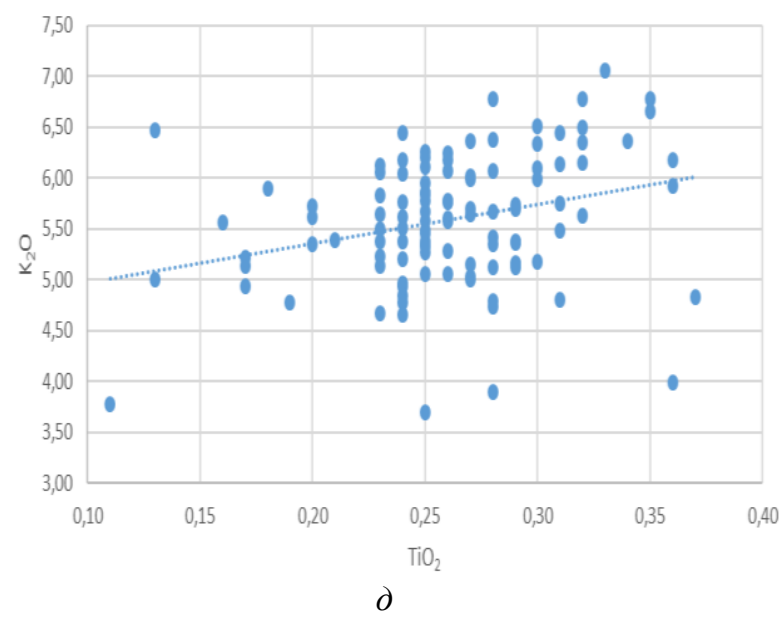

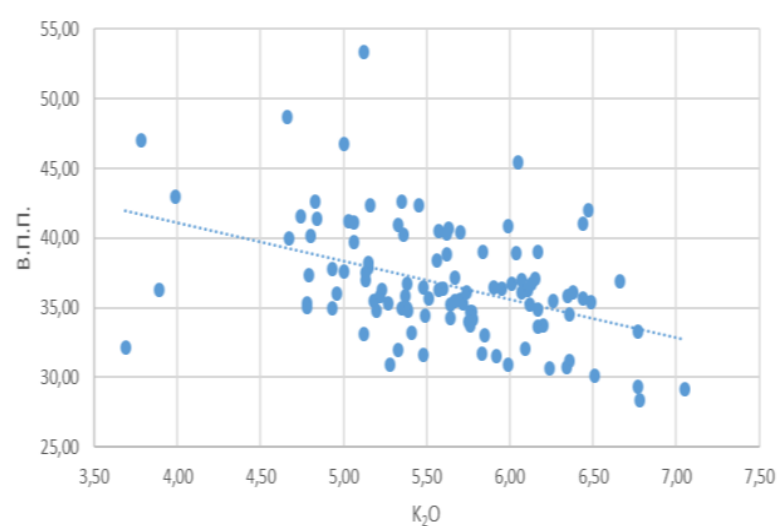

6

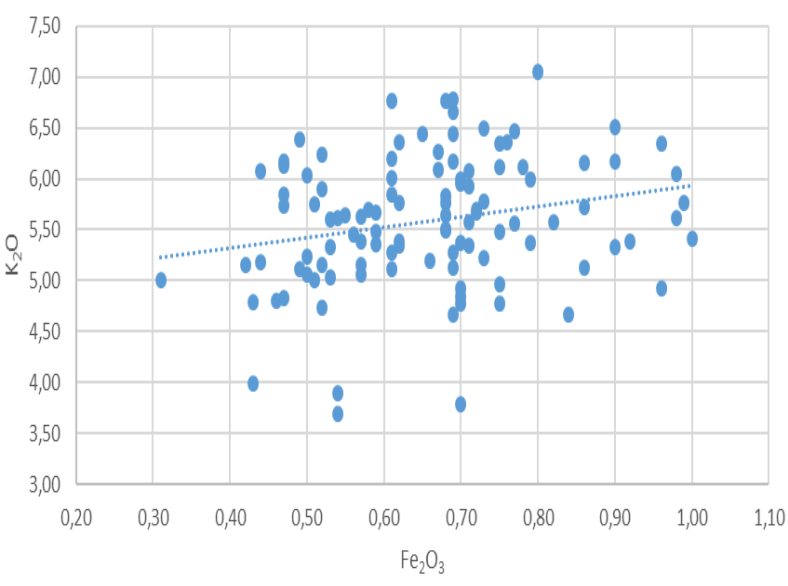

2

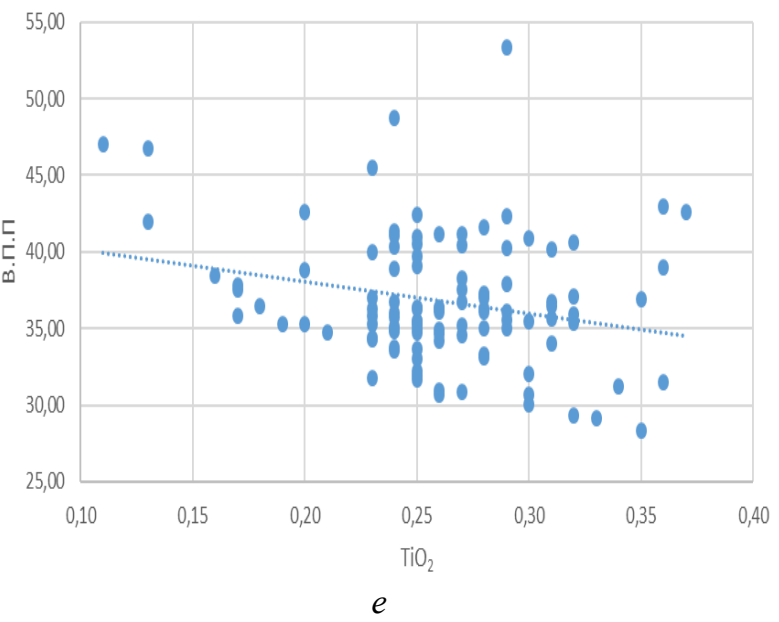

Рис. 1. Графіки залежності вмісту: а - двоокису титану від оксиду алюмінію; б - втрат при випалюванні від оксиду калію; в - оксиду калію від оксиду алюмінію; г - оксиду калію від оксиду заліза; д - оксиду калію від двоокису титану; е - втрат при випалюванні від двоокису титану

3 метою відображення отриманих залежностей та їх застосування для прогнозування хімічного складу каоліну в різних ділянках родовища, отримані залежності було описано за допомогою лінійних рівнянь. Лінійні рівняння для відображення залежності між різними складовими хімічними елементами каоліну наведено в таблиці 4.

Відповідно до результатів дослідження виділено найбільш інтенсивні зростаючі та спадаючі кореляційні залежності між окремими складовими хімічними елементами первинного каоліну Йосипівського родовища. Враховуючи той факт, що коефіцієнт кореляції Пірсона є відносною величиною, i не може бути використаним безпосередньо в математичних розрахунках, було схвалено рішення про доцільність відображення отриманих залежностей, які мають вигляд лінійних рівнянь (табл. 4). 
Лінійні рівняння для опису отриманих залежностей

\begin{tabular}{|c|c|c|c|c|}
\hline \multicolumn{2}{|c|}{ Компоненти, що розглядаються } & \multirow{2}{*}{$\begin{array}{l}\text { Лінійне рівняння для } \\
\text { описання залежності }\end{array}$} & \multirow{2}{*}{$\begin{array}{c}\text { Напрям } \\
\text { прямої }\end{array}$} & \multirow{2}{*}{ ККП } \\
\hline № 1 & № 2 & & & \\
\hline $\mathrm{TiO}_{2}$ & $\mathrm{Al}_{2} \mathrm{O}_{3}$ & $y=0,0144 x-0,0064$ & Зростаючий & $+0,41$ \\
\hline В.П.П & $\mathrm{K}_{2} \mathrm{O}$ & $y=-2,7488 x+52,113$ & Спадаючий & $-0,42$ \\
\hline $\mathrm{K}_{2} \mathrm{O}$ & $\mathrm{Al}_{2} \mathrm{O}_{3}$ & $y=0,1159 x+3,4301$ & Зростаючий & $+0,25$ \\
\hline $\mathrm{K}_{2} \mathrm{O}$ & $\mathrm{Fe}_{2} \mathrm{O}_{3}$ & $y=1,0167 x+4,9167$ & Зростаючий & $+0,23$ \\
\hline $\mathrm{K}_{2} \mathrm{O}$ & $\mathrm{TiO}_{2}$ & $y=3,473 x+4,5821$ & Зростаючий & $+0,29$ \\
\hline ВПП & $\mathrm{TiO}_{2}$ & $y=-20,875 x+42,207$ & Спадаючий & $-0,24$ \\
\hline
\end{tabular}

Виявлені кореляційні залежності мають такий характер:

- зростаючий кореляційний зв'язок середнього ступеня інтенсивності $(+0,41)$ між двоокисом титану та оксидом алюмінію, що говорить про зростання вмісту двоокису титану, яке зумовлюється зростанням вмісту оксиду алюмінію;

- спадаючий кореляційний зв'язок середнього ступеню інтенсивності $(-0,42)$ між втратами при пропалюванні та оксидом калію, що свідчить про зменшення вмісту оксиду калію, яке зумовлюється зменшенням вмісту втрат при пропалюванні.

Висновки та перспективи подальших досліджень. 3 огляду на значення ступеня інтенсивності отриманих залежностей, доцільно буде зробити висновок про їх недостатність задля ефективного використання у вирішенні питань практичного характеру, пов'язаних 3 проблематикою районування родовищ каоліну під час селективної розробки, або створення математичних моделей процесів усереднення та збагачення первинного каоліну. Причиною цього є низький ступінь інтенсивності зв'язку між досліджуваними парами складових хімічних елементів.

Однією з можливих причин відсутності кореляційних зв'язків високого ступеня інтенсивності може бути те, що аналіз даних і встановлення взаємозв'язків виконувався на всій території Йосипівського родовища первинного каоліну. Для аналізу було залучено занадто великий масив даних, сформований відповідно до результатів геологорозвідувальних робіт, у процесі виконання яких було пробурено 109 свердловин у межах контурів родовища, водночас для визначення хімічного складу каоліну, 3 кожної свердловини було відібрано по 3-4 проби, що в результаті дає близько 380 значень хімічного складу первинного каоліну з різними висотними та географічними відмітками. Зважаючи на це, доцільно буде зробити висновок, що саме такий факт міг мати вплив на низьку репрезентативність отриманих значень інтенсивності кореляційного зв'язку.

Водночас родовища каоліну насамперед характеризуються мінливістю хімічного складу, яка зумовлена особливостями їх формування. Відповідно, у різних частинах родовища буде локалізована одна i та ж порода, але зі значними відмінностями у хімічному складі. Отже, 3 метою підвищення репрезентативності кореляційних взаємозв'язків, отриманих за допомогою методу Пірсона, пропонується виконувати їх пошук на окремих невеликих ділянках родовища з прив'язкою до висотних та географічних координат. Розміри таких ділянок доцільно буде розглядати кратними розмірам параметрів системи розробки родовища.

\section{Список використаної літератури:}

1. Про затвердження інструкції із застосування Класифікації запасів і ресурсів корисних копалин державного фонду надр до родовищ каоліну : наказ № 354 станом на 20.12.2006 р. / Державна комісія України по запасах корисних копалин при міністерстві охорони навколишнього природного середовища України. - Київ : Міністерство юстиції України, 2007. - 41 с.

2. Moore B.A. Correlation and regression analysis: applications to the analysis of chemical data / B.A. Moore // Analytical Proceedings 17. - 1980. - 124 p.

3. Lee J. Thirteen ways to look at the correlation coefficient / J.Lee, W.Alan. - Portland : American statistical association, 1988. $-59 \mathrm{p}$.

4. Bartlett R.F. Linear modelling of Pearson's correlation coefficient: an application of Fisher's z-transformation / R.F. Bartlett // The Statistician 42. - 1993. - 43 p.

5. Білеиький В.С. Моделювання процесів збагачення корисних копалин : монографія / В.С. Білецький, B.О. Смирнов. - Донецьк : Східний видавничий дім, 2013. - 204 с.

6. Детальна геолого-економічна оцінка Йосипівського родовища первинного каоліну у Баранівському районі Житомирської області : звіт про розвідку родовища твердих корисних копалин станом на 01.07.2007 p. $/$ Державна геологічна служба України при Міністерстві охорони навколишнього природного середовища України. - Київ : Північне державне регіональне геологічне підприємство «Північгеологія», 2007. - 184 с.

7. Клапоущак O.I. Встановлення взаємозв'язку між даними / O.I. Клапоущак // Проблеми статистичного аналізу даних : збірка статей. - Івано-Франківськ : ІФНТУНГ, 2014. - 34 с. 
8. Massart D.L. The Interpretation of Analytical Chemistry Data by the Use of Cluster Analysis / D.L. Massart, L.Kaufman. - New York : John Wiley \& Sons, 1983. - P. 15.

9. Cook R.D. An Introduction to Regression Graphics / R.D. Cook, S.Weisberg. - New York : John Wiley \& Sons, 1994. - P. 12.

\section{References:}

1. Derzhavna komisija Ukrai'ny po zapasah korysnyh kopalyn pry ministerstvi ohorony navkolyshn'ogo pryrodnogo seredovyshha Ukrai'ny (2007), Pro zatverdzhennja instrukcii' iz zastosuvannja Klasyfikacii' zapasiv $i$ resursiv korysnyh kopalyn derzhavnogo fondu nadr do rodovyshh kaolinu, Nakaz No. 354 stanom na 20.12.2006 r., Ministerstvo justycii' Ukrai'ny, Kyi'v, 41 p.

2. Moore, B.A. (1980), «Correlation and regression analysis: applications to the analysis of chemical data», Analytical Proceedings 17, $124 \mathrm{p}$.

3. Lee, J. and Alan, W. (1988), Thirteen ways to look at the correlation coefficient, American statistical association, Portland, $59 \mathrm{p}$.

4. Bartlett, R.F. (1993), «Linear modelling of Pearson's correlation coefficient: an application of Fisher's ztransformation», The Statistician 42, $43 \mathrm{p}$.

5. Bilec'kyj, V.S. and Smyrnov, V.O. (2013), Modeljuvannja procesiv zbagachennja korysnyh kopalyn, monografija, Shidnyj vydavnychyj dim, Donec'k, 204 p.

6. Derzhavna geologichna sluzhba Ukrai'ny pry Ministerstvi ohorony navkolyshn'ogo pryrodnogo seredovyshha Ukrai'ny (2007), Detal'na geologo-ekonomichna ocinka Josypivs'kogo rodovyshha pervynnogo kaolinu $u$ Baranivs'komu rajoni Zhytomyrs'koi' oblasti, zvit pro rozvidku rodovyshha tverdyh korysnyh kopalyn stanom na 01.07.2007 r., Pivnichne derzhavne regional'ne geologichne pidpryjemstvo «Pivnichgeologija», Kyi'v, 184 p.

7. Klapoushhak, O.I. (2014), «Vstanovlennja vzajemozv’jazku mizh danymy», Problemy statystychnogo analizu danyh, zbirka statej, IFNTUNG, Ivano-Frankivs'k, 34 p.

8. Massart, D.L. and Kaufman, L. (1983), The Interpretation of Analytical Chemistry Data by the Use of Cluster Analysis, John Wiley \& Sons, New York, p. 15.

9. Cook, R.D. and Weisberg, S. (1994), An Introduction to Regression Graphics, John Wiley \& Sons, New York, p. 12.

Котенко Володимир Володимирович - кандидат технічних наук, доцент Державного університету «Житомирська політехніка».

http://orcid.org/0000-0001-8764-1692.

Наукові інтереси:

- відкрита розробка родовищ корисних копалин;

- геометризація родовищ корисних копалин.

Башинський Сергій Іванович - кандидат технічних наук, доцент Державного університету «Житомирська політехніка».

http://orcid.org/0000-0002-2945-7683.

Наукові інтереси:

- відкрита розробка родовищ корисних копалин;

- моделювання процесів гірничого виробництва.

Піскун Ігор Анатолійович - аспірант, асистент Державного університету «Житомирська політехніка». https://orcid.org/0000-0002-1658-5344.

Наукові інтереси:

- відкрита розробка родовищ корисних копалин;

- дослідження якісних показників родовищ корисних копалин.

Стаття надійшла до редакції 11.10.2021. 